\title{
Purification of geranylgeranyltransferase I from Candida albicans and cloning of the CaRAM2 and CaCDC43 genes encoding its subunits
}

Department of

Biochemistry, Merck

Research Laboratories,

RY80Y-200, PO Box 2000,

Rahway, NJ 07065, USA

\author{
Paul Mazur, Elizabeth Register, Cynthia A. Bonfiglio, Xiling Yuan, \\ Myra B. Kurtz, Joanne M. Williamson and Rosemarie Kelly
}

Author for correspondence: Rosemarie Kelly. Tel: +1 732594 6385. Fax: +1 7325945468. e-mail: rosemarie_kelly $(a)$ merck.com

\begin{abstract}
All previously characterized protein geranylgeranyltransferases I (GGTase I) are heterodimeric zinc metalloenzymes which catalyse geranylgeranylation of a cysteine residue in proteins containing a C-terminal CaaL motif (C, Cys; a, aliphatic amino acid; L, Leu). The $\alpha$ and $\beta$ subunits of GGTase I of Saccharomyces cerevisiae are encoded by RAM2 and CDC43, respectively, and are essential for yeast viability. The authors are therefore investigating the role of geranylgeranylation in the related pathogenic yeast, Candida albicans, which is the most prevalent human fungal pathogen. GGTase I was purified to near homogeneity and also found to be a heterodimeric magnesiumdependent, zinc metalloenzyme displaying selectivity for CaaL-containing protein substrates. GGTase I peptide sequences were obtained from the purified protein and used to clone the genes encoding both subunits. CaRAM2 and CaCDC43 encode proteins that are 42 and $34 \%$ identical to their corresponding S. cerevisiae homologues, respectively, and $30 \%$ identical to their human homologues. Despite the limited overall homology, key zinc- and substrate-binding residues of the $\beta$ subunit (Cdc43p) are conserved. A unique feature of $\mathrm{CaCdc43p}$ is a tract of polyasparagine whose length varies from 6 to 17 residues among $C$. albicans strains and between alleles. Coexpression of both CaCDC43 and CaRAM2 under their native promoters complemented the ts defect of a S. cerevisiae cdc43 mutant but expression of the $\beta$-subunit alone did not correct the growth defect, suggesting that hybrid GGTase I heterodimers are nonfunctional.
\end{abstract}

Keywords: Candida albicans, protein prenylation, protein geranylgeranyltransferase I, heterologous expression

\section{INTRODUCTION}

Prenylation is a post-translational modification that facilitates membrane localization of a protein by increasing its hydrophobicity, and is often essential for

\footnotetext{
Abbreviations: FPP, farnesyl diphosphate; FTase, farnesyltransferase; 5 FOA, 5-fluoroorotic acid; GGPP, geranylgeranyl diphosphate; GGTase, geranylgeranyltransferase.

The GenBank accession numbers for the sequences determined in this work are AF110690 and AF110691.
}

function (Schafer \& Rine, 1992; Omer \& Gibbs, 1994). One class of protein prenyltransferases consists of heterodimeric zinc-dependent enzymes catalysing prenyl group transfer from either farnesyl diphosphate (farnesyltransferase; FTase) or geranylgeranyl diphosphate (geranylgeranyltransferase I; GGTase I). The prenyl group is linked to a cysteine residue in the Cterminal amino acid sequence referred to as a CaaX motif [C, cysteine; a (usually), aliphatic amino acid; X, any amino acid]. The specificity of prenyl group addition is largely determined by the X-residue of the CaaX motif (Zhang \& Casey, 1996a). Following prenylation, the 
three $\mathrm{C}$-terminal amino acids are removed by proteolysis and the free carboxyl group of the prenyl-cysteine is carboxy-methylated (Clarke, 1992). A second and distinct class of protein prenyltransferases found in yeast and mammalian cells is GGTase II, which specifically catalyses geranylgeranylation at both cysteines of Cterminal -CC or -CXC sequences found in yeast $\mathrm{Rab}$ proteins (Farnsworth et al., 1994; Zhang \& Casey, 1996a).

GGTase I has a preference for substrates in which X of the CaaX motif is leucine, whereas FTase farnesylates proteins that terminate in alanine, cysteine, glutamine, methionine or serine (Moores et al., 1991; Caplin et al., 1994). The $\alpha$ and $\beta$ subunits of GGTase I from Saccharomyces cerevisiae are encoded by RAM2 and $C D C 43$, respectively, and each is essential for viability (Adams et al., 1990; Finegold et al., 1991; He et al., 1991; Ohya et al., 1991; Mayer et al., 1992). FTase shares a common $\alpha$ subunit with GGTase I in both yeast and mammals. RAM1 encodes the $\beta$ subunit of $S$. cerevisiae FTase, and null mutants of this gene exhibit a temperature-sensitive lethality (He et al., 1991; Kohl et al., 1991).

Geranylgeranylated proteins are typically small GTPbinding proteins involved in cytokinesis, cell polarity and morphogenesis (Schafer \& Rine, 1992). The two most critical substrates of $S$. cerevisiae GGTase I appear to be the essential proteins Cdc42p and Rho1p, since the simultaneous overexpression of both suppresses a GGTase I defect (Ohya et al., 1993; Trueblood et al., 1993). Compensation presumably occurs by FTasemediated prenylation of these substrates, since FTase, not normally essential, becomes required for cell viability in this situation. Rho1p has at least three important roles in morphogenesis in S. cerevisiae: (1) it is required as an activator of protein kinase $\mathrm{C}$, which plays a fundamental and essential role in maintaining cell wall integrity (Nonaka et al., 1995; Kamada et al., 1996) ; (2) it has been shown to activate Bin1p, a protein involved in reorganization of the actin cytoskeleton during polarized morphogenesis (Kohno et al., 1996; Imamura et al., 1997); and (3) it has been identified as the GTP-binding regulatory subunit of $1,3-\beta$-D-glucan synthase, an essential enzyme involved in fungal cell wall biosynthesis (Drgonová et al., 1996; Mazur \& Baginsky, 1996; Qadota et al., 1996). In this last role, Rho1p is found associated with Fks1p, an essential subunit of $S$. cerevisiae $1,3-\beta$-D-glucan synthase (Douglas et al., 1994).

Candida albicans, a dimorphic yeast related to $S$. cerevisiae, is a major opportunistic human fungal pathogen, causing life-threatening infections in many immunocompromised patients (Cox \& Perfect, 1993). We are interested in exploiting cell wall synthesis and related processes, such as protein prenylation, for antifungal targets. The recent confirmation of CaRho1p as the regulatory subunit of glucan synthase in $C$. albicans (Kondoh et al., 1997) suggests that the essential regulatory role of the RHO-family GTPases is conserved in Candida species. Rho1p (Kondoh et al., 1997) and Cdc42p (Mirbod et al., 1997) of C. albicans contain CaaL motifs and are probably GGTase I substrates. Hence GGTase I may play an important role in morphogenesis and cell wall biosynthesis in C. albicans. Here we report the purification of GGTase I from $C$. albicans and the subsequent cloning and sequence analysis of its subunits. We show that despite the limited overall homology of the subunits to those of other organisms, key structural and substrate-recognition elements of the $\beta$ subunit $(\mathrm{Cdc} 43 \mathrm{p})$ are conserved. Function of the cloned C. albicans genes was confirmed by complementation of a $S$. cerevisiae conditional GGTase I mutant.

\section{METHODS}

General. Chromatography columns and media were from Pharmacia. Protein concentrations were determined with the BCA protein assay reagent (Pierce) or Protein-Gold reagent (Integrated Separation Systems) with BSA as the standard. SDS-PAGE gels were from Novex.

Yeast strains, growth media and microbiological methods. CJ198-2B (MAT $\alpha c d c 43-2$ ura3 trp1 his4 gal2) is a ts $c d c 43 \mathrm{~S}$. cerevisiae mutant kindly provided by D. Johnson (Adams et al., 1990). RS51-3A (MAT $\alpha$ ram2-1 ura3 his3 ade8 trp1 can1 $R A S 2^{\text {val19 }}$ ) is a ts ram 2 mutant obtained from S. Powers (Goodman et al., 1990). S. cerevisiae diploid W303 (MATa/ MAT $\alpha$ ade2-1/ade2-1 can1-100/can1-100 his3-11,15/his311,15 leu2-3,112/leu2-3,112 trp1-1/trp1-1 ura3-1/ura3-1) was constructed by mating haploid W303-1A and W303-1B (Thomas \& Rothstein, 1989). S. cerevisiae S288C (MAT $\alpha$ ) was obtained from the Yeast Genetics Stock Center. C.

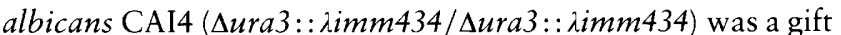
of W. Fonzi (Fonzi \& Irwin, 1993) and MY1055 is a clinical isolate (Abruzzo et al., 1995). Mating and sporulation of yeast strains, and tetrad dissections, were performed as described and all media were standard for yeast genetics (Sherman $e t$ al., 1986).

Protein prenyltransferase assays. Protein prenyltransferase activities were routinely determined by an acid quenchfiltration assay with prenyl acceptor substrates based on $S$. cerevisiae Ras1p (Moores et al., 1991). The protein substrates, referred to as Ras-CaaX, were expressed in Escherichia coli from the previously described plasmids $\left[{ }^{68} \mathrm{Leu}\right] \mathrm{RAS} 1$ (term.)SLKCaaX (CaaX = CAIL, CVLS, CVLM) obtained from C. Omer (Moores et al., 1991). Additional Ras-CaaX plasmids (CaaX = CVIL, CTIL, CVVL, CVIA) were constructed by the strategy previously described (Moores et al., 1991). The integrity of Ras-CaaX protein samples was verified by massspectroscopic analysis. Typical GGTase I reactions were performed under either of two sets of conditions: $50 \mathrm{mM}$ Bistris propane $\mathrm{pH} 9 \cdot 0,10 \mathrm{mM} \mathrm{MgCl}, 0 \cdot 1 \mathrm{mM} \mathrm{ZnCl}_{2}, 0 \cdot 05 \%$ (w/v) dodecyl maltoside, $2-4 \mu \mathrm{M}\left[{ }^{3} \mathrm{H}\right]$ geranylgeranyl diphosphate $\left({ }^{3} \mathrm{H}-\mathrm{GGPP}\right), 20 \mu \mathrm{M}$ Ras-CAIL or Ras-CVIL; or $50 \mathrm{mM}$ HEPES pH 7.5, 1-5 mM DTT, $10 \mathrm{mM} \mathrm{MgCl}_{2}, 0.05 \mathrm{mM}$ $\mathrm{ZnCl}_{2}, 0.05 \%$ dodecyl maltoside, $2-4 \mu \mathrm{M}{ }^{3} \mathrm{H}$-GGPP, $20 \mu \mathrm{M}$ Ras-CAIL or Ras-CVIL. Detergent was required to maintain GGPP solubility and in some cases $0.02 \%(\mathrm{w} / \mathrm{v})$ Triton X-100 was substituted for the $0.05 \%$ dodecyl maltoside with little change in enzyme activity. Typical conditions for measurement of FTase activity were $50 \mathrm{mM}$ HEPES pH 7.5, $1 \mathrm{mM}$ $\mathrm{MgCl}_{2}, 0 \cdot 1 \mathrm{mM} \mathrm{ZnCl}, 0 \cdot 05 \%$ dodecyl maltoside, $2-4 \mu \mathrm{M}$ $\left[{ }^{3} \mathrm{H}\right]$ farnesyl diphosphate $\left({ }^{3} \mathrm{H}-\mathrm{FPP}\right), 20 \mu \mathrm{M}$ Ras-CVLS or Ras- 
CVLM. All reactions were performed in duplicate and were initiated by addition of prenyltransferase activity to a final volume of 25 or $50 \mu \mathrm{l}$ in polypropylene 96 -well plates or microcentrifuge tubes, respectively, and incubated at $30^{\circ} \mathrm{C}$ for $30-90 \mathrm{~min}$. Reaction samples $\langle 25 \mu \mathrm{l}\rangle$ were quenched by addition of $200 \mu \mathrm{l} 10 \%(\mathrm{v} / \mathrm{v})$ concentrated $\mathrm{HCl} /$ ethanol, incubated at $37^{\circ} \mathrm{C}$ for $30 \mathrm{~min}$, then vacuum filtered through Whatman GF/B filters and rinsed with ethanol. Dried filters were subjected to liquid scintillation counting (Beckman Ready Safe). ${ }^{3} \mathrm{H}-\mathrm{GGPP}\left[12-20 \mathrm{Ci}\left(4 \cdot 4-7 \cdot 4 \times 10^{11} \mathrm{~Bq}\right) \mathrm{mmol}^{-1}\right]$ and ${ }^{3} \mathrm{H}-\mathrm{FPP}\left[15-20 \mathrm{Ci}\left(5 \cdot 6-7 \cdot 4 \times 10^{11} \mathrm{~Bq}\right) \mathrm{mmol}^{-1}\right]$ were purchased from Amersham and typically used in assays at 1000-2000 d.p.m. pmol $^{-1}$; non-radioactive GGPP and FPP were purchased from American Radiolabelled Chemicals. For the determination of Michaelis constants for Ras-CVIL and GGPP, purified GGTase I was assayed in $50 \mathrm{mM}$ HEPES $\mathrm{pH} 7 \cdot 5,10 \mathrm{mM} \mathrm{MgCl}, 0.1 \mathrm{mM} \mathrm{ZnCl}_{2}$ and $0.02 \%$ Triton X100 containing the varied substrate and $2 \mu \mathrm{M}{ }^{3} \mathrm{H}$-GGPP or $50 \mu \mathrm{M}$ Ras-CVIL, respectively. $K_{\mathrm{m}}$ values were determined by fitting saturation curves to $V=V_{\max } \cdot c /\left(K_{\mathrm{m}}+c\right)$.

Purification of C. albicans GGTase I. C. albicans MY1055 cultures were grown overnight in YPD at $30^{\circ} \mathrm{C}$, harvested by centrifugation at an $\mathrm{OD}_{600}$ of $10-15$ (approx. $20 \mathrm{~g}$ cell paste $\left.\mathrm{I}^{-1}\right)$, and stored at $-80^{\circ} \mathrm{C}$. All purification procedures were conducted at $4{ }^{\circ} \mathrm{C}$. The cell paste $(36 \mathrm{~g})$ was thawed in an equal volume of lysis buffer containing $50 \mathrm{mM}$ Bistris propane $/ \mathrm{HCl}, \mathrm{pH} 7,1 \mathrm{mM} \beta$-mercaptoethanol, $1 \times$ Complete protease inhibitor cocktail (Boehringer Mannheim) and $1 \mathrm{mM}$ Pefabloc protease inhibitor (Boehringer Mannheim). The cell slurry was homogenized with an equal volume of $0.5 \mathrm{~mm}$ glass beads for $30 \mathrm{~s}$ and cooled for $2.5 \mathrm{~min}$ in an ice-cooled BeadBeater (Biospec); this cycle was repeated 8-10 times. The crude homogenate was centrifuged at $31000 \mathrm{~g}$ for $15 \mathrm{~min}$ at $4{ }^{\circ} \mathrm{C}$ and the supernatant $(89 \mathrm{ml})$ subjected to buffer exchange by gel filtration on Sephadex G-25 $(2.6 \times 70 \mathrm{~cm})$ equilibrated in buffer A $(20 \mathrm{mM}$ Bistris propane $/ \mathrm{HCl}, \mathrm{pH} 7,0.02 \mathrm{mM}$ $\mathrm{ZnCl}_{2}, 1 \mathrm{mM} \mathrm{MgCl}$ ). The eluate containing the protein peak was clarified by ultracentrifugation at $100000 \mathrm{~g}$ for $1 \mathrm{~h}$ at $4{ }^{\circ} \mathrm{C}$. After centrifugation, the supernatant was retained and loaded onto a Q-Sepharose HP column $(2.6 \times 24 \mathrm{~cm})$ equilibrated in buffer $\mathrm{A}$. The column was washed with buffer $\mathrm{A}$ and eluted with a 10 -column volume linear gradient of $\mathrm{NaCl}(0-0.5 \mathrm{M})$ in buffer $A$ at a flow rate of $3 \mathrm{ml} \mathrm{min}^{-1}$ and fractions $(15 \mathrm{ml}$ ) were collected. This step completely resolved GGTase I activity (eluted at $0.3 \mathrm{M} \mathrm{NaCl}$ ) from FTase activity (eluted at $0.35 \mathrm{M}$ $\mathrm{NaCl}$ ). Fractions containing the GGTase I activity were pooled $(75 \mathrm{ml})$, adjusted to $0.8 \mathrm{M}$ ammonium sulfate by the addition of solid ammonium sulfate $(8 \cdot 1 \mathrm{~g})$, and the sample applied to a Phenyl Sepharose HP column $(1.6 \times 5 \mathrm{~cm})$ equilibrated in buffer A plus $0.8 \mathrm{M}$ ammonium sulfate. The column was washed in buffer A plus $0.8 \mathrm{M}$ ammonium sulfate and eluted with a 10-column volume descending linear gradient of ammonium sulfate $(0 \cdot 8-0 \mathrm{M})$ in buffer $\mathrm{A}$ at a flow rate of $2.5 \mathrm{ml} \mathrm{min}{ }^{-1}$. Fractions $(2.5 \mathrm{ml})$ were collected and those containing GGT ase I activity were pooled (eluted at $0.4-0.2 \mathrm{M}$ ammonium sulfate; $27.5 \mathrm{ml}$ ), dialysed into buffer $\mathrm{A}$, concentrated $(0.28 \mathrm{ml})$ with concentrating solution (Pierce) and/or by ultrafiltration ( $30 \mathrm{kDa}$ cutoff; Amicon), and subjected to gel filtration on a Superdex-200 HR 10/30 FPLC column equilibrated in buffer $A$. The column was eluted at a flow rate of $0.4 \mathrm{ml} \mathrm{min} \mathrm{m}^{-1}$ and fractions $(0.2 \mathrm{ml})$ were collected. The GGTase I activity was pooled and applied to a Mono-Q HR $5 / 5$ FPLC column equilibrated in buffer $A$ and eluted with a two-step $\mathrm{NaCl}$ gradient $(0-0.35 \mathrm{M}$ in $5 \mathrm{ml} ; 0.35-0.7 \mathrm{M}$ in

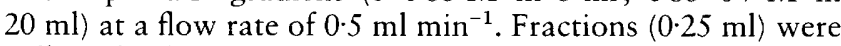
collected. The GGTase I activity eluted as an apparent single peak at approximately $0.38 \mathrm{M} \mathrm{NaCl}$. The pooled activity was dialysed into buffer $\mathrm{A}$ and stored at $-80^{\circ} \mathrm{C}$. The FTase activity could be further purified by Phenyl-Sepharose chromatography under the same conditions as described above for GGTase I. The FTase activity eluted at $0 \cdot 2-0 \mathrm{M}$ ammonium sulfate and was pooled, dialysed into buffer $\mathrm{A}$, and stored at $-20^{\circ} \mathrm{C}$ (significant loss of activity occurred when the preparation was stored at $-80^{\circ} \mathrm{C}$ ).

Protein chemistry. Approximately $5 \mu \mathrm{g}(\sim 60 \mathrm{pmol})$ purified GGTase I was subjected to electrophoresis on a $10 \%$ Tris/glycine SDS-PAGE gel and blotted to PVDF (Bio-Rad). The blot was stained with Ponceau S (Sigma) and the two main bands detected (approx. 41 and $45 \mathrm{kDa}$ ) were excised. Trypsin digest/HPLC and peptide sequencing/mass spectroscopic analyses were performed by the Harvard University Microchemistry facility. Two sequences were obtained from the $41 \mathrm{kDa}$ subunit [41-1, NF(W or T)DYQ; and 41-2, LHITELGINELASHYT] and five sequences from the $45 \mathrm{kDa}$ subunit [45-1, DIGGFNGR; 45-2, DYPENLYPK; 45-3, TQNQLFGGFGR; 45-4, FALQEINPILTITK; and 45-5, GGFVPTLYYNEENXDY].

Nucleic acid isolation, hybridization, and sequence analysis. Plasmid DNA was isolated using the QIAprep spin miniprep or QIAGEN-tip 500 or 100 kits (QIAGEN). Genomic DNA of C. albicans was isolated by the glass-bead lysis method of Hoffman \& Winston (1987). All DNA blots were performed with Zeta-ProbeGT derivatized nylon membranes (Bio-Rad) and were hybridized under stringent conditions recommended by the manufacturer. The probes were radiolabelled with $[\alpha-$ $\left.{ }^{32} \mathrm{P}\right] \mathrm{dCTP}$ using a random-primed DNA labelling kit (Stratagene). The DNA sequence of both strands of designated clones was determined on a model $377 \mathrm{~A}$ automated DNA sequencer with a Prism Ready Reaction DyeDeoxy Terminator Cycle Sequencing kit (Applied Biosystems). Sequences were assembled with Gene Codes Corporation Sequencher 3.0 and analysed primarily with the Genetics Computer Group software package. Percentage identity between protein sequences was determined with the GAP program. Multiple sequence alignments were performed by the CLUSTAL program (Thompson et al., 1994).

Cloning of the GGTase I subunit genes. Fragments of $C a C D C 43$ and CaRAM2 were amplified from genomic $C$. albicans DNA by PCR with degenerate oligonucleotide primers encoding the least degenerate regions of the determined GGTase I peptide sequences (Compton, 1990). In unavoidable cases where sequencing indicated two possible amino acids or a primer encoded an amino acid potentially encoded by five or more codons $(\mathrm{L}, \mathrm{S}, \mathrm{R})$, primer degeneracy was minimized by preparing two separate primer pools. PCR products were purified and directly subcloned into pCR2.1 (Invitrogen) for DNA sequencing. PCRs with the primers (EcoRI linkers are underlined) 5' GCG CGC GAA TTC (T/C)TG (G/A)TA (G/A)TC CCA (G/A)AA (G/A)TT 3' (antisense) and $5^{\prime}$ GCG CGC GAA TTC GA(G/A) CT(A/ $\mathrm{C} / \mathrm{T}) \mathrm{GG}(\mathrm{A} / \mathrm{C} / \mathrm{T} / \mathrm{G}) \mathrm{AT}(\mathrm{A} / \mathrm{C} / \mathrm{T}) \mathrm{AA}(\mathrm{C} / \mathrm{T}) \mathrm{GA}(\mathrm{G} / \mathrm{A}) 3^{\prime}$ (sense), encoding regions of peptides 41-1 (NFWDYQ) and 412 (ELGINE), respectively, generated a predominant $729 \mathrm{bp}$ PCR product (pCaRAM2-9) from C. albicans CAI4 DNA. The PCR reactions ( $50 \mu \mathrm{l}$ volume) contained $100 \mathrm{ng}$ genomic DNA, $1 \cdot 0 \mu \mathrm{M}$ each primer, $3 \mathrm{mM} \mathrm{Mg}{ }^{2+}, 200 \mu \mathrm{M}$ each dNTP and 1.25 units Taq polymerase (Fisher Biotech). The thermalcycler profile $\left(40\right.$ cycles) was $94^{\circ} \mathrm{C}$ for $1 \mathrm{~min}, 50^{\circ} \mathrm{C}$ for 1 $\min , 72^{\circ} \mathrm{C}$ for $2 \mathrm{~min}$, followed by a final incubation at $72{ }^{\circ} \mathrm{C}$ for $10 \mathrm{~min}$. The DNA sequence of this product suggested that it encoded a peptide of C. albicans Ram $2 \mathrm{p}$ by homology to $S$. cerevisiae Ram 2 p. Likewise, sense and antisense degenerate 
oligonucleotides $\quad 5^{\prime} \quad$ GCG CGC GAA TTC TA(C/T) $\mathrm{TA}(\mathrm{C} / \mathrm{T}) \mathrm{AA}(\mathrm{C} / \mathrm{T}) \mathrm{GA}(\mathrm{A} / \mathrm{G}) \mathrm{AA}(\mathrm{A} / \mathrm{G}) \mathrm{AA}(\mathrm{C} / \mathrm{T}) 3^{\prime}$ and $5^{\prime}$ GCG CGC GAA TTC (A/C/G/T)CC (G/A)AA (T/C)AA (T/C)TG (G/A)TT (T/C)TG 3' partially encoding peptide 45-5 (YYNEEN) and encoding 45-3 (QNQLFG), respectively, were employed in PCRs with C. albicans MY1055 genomic DNA as template. The PCR reactions were performed as described above with a thermalcycler profile of (35 cycles) $94{ }^{\circ} \mathrm{C}$ for $1 \mathrm{~min}, 40^{\circ} \mathrm{C}$ for $1 \mathrm{~min}, 72^{\circ} \mathrm{C}$ for $1 \mathrm{~min}$, followed by a final incubation at $72{ }^{\circ} \mathrm{C}$ for $10 \mathrm{~min}$. A $573 \mathrm{bp} \mathrm{PCR} \mathrm{product}$ (pCR2.1-600) was obtained whose DNA sequence revealed an open reading frame which encoded peptides 45-1 and 45-2 in addition to exhibiting homology to $S$. cerevisiae Cdc43p.

To isolate genomic clones of each subunit, probes derived from the PCR clones of each gene were used to screen a $C$. albicans genomic library, CLS2, that had been constructed from strain CA124 in the S. cerevisiae vector YEp24 and was obtained from J. Rosamond (Sherlock et al., 1994). The CaRAM2 and CaCDC43 probes were a radiolabelled $0.6 \mathrm{~kb}$ NheI-XbaI fragment from pCaRAM2-9 and a $0.6 \mathrm{~kb} E c o \mathrm{RI}$ fragment from pCR2.1-600, respectively. Four independent CaRAM2 and three $\mathrm{CaCDC4} 3$ clones that hybridized to their respective probes were isolated. The clones for each subunit had insert sizes ranging from approximately 5 to $7 \mathrm{~kb}$ and contained common overlapping restriction fragments. Restriction and partial sequence analysis indicated that the clones contained full-length genes based on comparison of predicted peptide sequences to their $S$. cerevisiae counterparts. One CaRAM2 clone, pCaRAM16, and one CaCDC43 clone, pCaCDC7, contained approximately $3.0 \mathrm{~kb}$ HindIII fragments that were collinear with genomic DNA and were chosen for completion of sequence determination and further analysis.

Primers based on sequence of the genomic clones were used to amplify the genes from genomic DNA of C. albicans strains CAI4 and MY1055 by PCR. A CaRAM2 PCR product, encompassing the entire coding region as well as $1279 \mathrm{bp}$ upstream and $404 \mathrm{bp}$ downstream from the ORF, was amplified from CAI4 with the primers 5' GCGCGCTGCAGCATAAGGGATCAACGCCG $3^{\prime}$ and 5' CCGGCGGTACCAGGAGAAAATTGATTCCCCG 3' (underlined sequences are $P s t \mathrm{I}$ and $K p n \mathrm{I}$ restriction sites, respectively). A $\mathrm{CaCDC43}$ PCR product, containing the entire coding region as well as 647 bp $5^{\prime}$ and 733 bp $3^{\prime}$ of the ORF, was amplified from CAI4 with primers 5' GCGCTCTAGACGTATAAACCCTTGTCCCG $3^{\prime}$ and $5^{\prime}$ CCGCGGTACCTTGAAGGTAATGTAC-

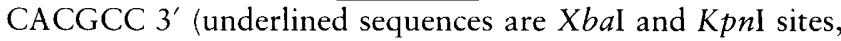
respectively). The PCR reactions $(50 \mu \mathrm{l}$ volume) contained

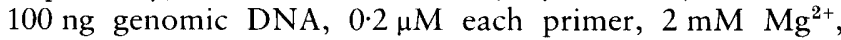
$200 \mu \mathrm{M}$ each dNTP, 1 unit Elongase and $1 \times$ buffers A and B (GibcoBRL). Cycle profile ( 30 cycles) was $94^{\circ} \mathrm{C}$ for $1 \mathrm{~min}$, $55^{\circ} \mathrm{C}$ for $1 \mathrm{~min}, 72^{\circ} \mathrm{C}$ for $6 \mathrm{~min}$, followed by a final incubation at $72^{\circ} \mathrm{C}$ for $20 \mathrm{~min}$. The CaRAM2 and $\mathrm{CaCDC} 43 \mathrm{PCR}$ products were cloned into YEplac181 $\left(\mathrm{Leu}^{+} ;\right.$Gietz \& Sugino, 1988) and pUC19 (Yanisch-Perron et al., 1985), respectively. Five clones of each gene were sequenced and the data indicated that four clones of one allele and one clone of the other allele were isolated. Plasmids pCaRAM2-22 and pCaCDC43-43 contain the most frequently isolated allele of each gene while pCaRAM2-25 and pCaCDC43-40 harbour the other allele. Similarly, a CaRAM2 PCR product encompassing the complete ORF and $131 \mathrm{bp}$ of $5^{\prime}$ and $155 \mathrm{bp}$ of $3^{\prime}$ non-coding sequence was amplified from MY1055 DNA with the primers $5^{\prime}$ GCGGGATCCTCATGAACTTTTCAAACAAACCA 3' and $5^{\prime}$ GCGGGATCCCTTAATTGATTTGCAATCATTCCT 3' (underlined sequences are BamHI sites). A CaCDC43 PCR product containing the ORF and $159 \mathrm{bp}$ of $5^{\prime}$ and $173 \mathrm{bp}$ of $3^{\prime}$ non-coding sequence was amplified from MY1055 DNA with the primers 5' GCGGGATCCTCACCGCACACCAAAAAGTA $3^{\prime}$ and $5^{\prime}$ GCGGGATCCTGTGGGAGAACACTCCGATT $3^{\prime}$. The PCR reactions $(50 \mu \mathrm{l})$ contained $1 \times$ reaction buffer, $100 \mathrm{ng}$ genomic DNA, $0.5 \mu \mathrm{M}$ primers, $200 \mu \mathrm{M}$ each dNTP and 2 units $P f u$ (Stratagene) or Vent (NEB) polymerase. The cycle profile ( 30 cycles) was $94^{\circ} \mathrm{C}$ for $1 \mathrm{~min}$, $50{ }^{\circ} \mathrm{C}$ for $1 \mathrm{~min}, 72{ }^{\circ} \mathrm{C}$ for $3-4 \mathrm{~min}$. T-overhangs were added with Taq polymerase and the PCR products cloned into pCR2.1 (Invitrogen). Six clones were sequenced for each product. Three clones were obtained from each CaRAM2 allele as exemplified by pCR2.1-RAM2-21 and pCR2.1RAM2-27; four and two clones were obtained for the two $\mathrm{CaCDC43}$ alleles and are represented by pCR2.1-CDC43-24 and pCR2.1-CDC43-14, respectively.

Construction of CaCDC43 and CaRAM2 subclones in $S$. cerevisiae vectors. The $3.0 \mathrm{~kb}$ CaRAM2 HindIII fragment from genomic clone pCaRAM16 was subcloned into YEplac$112\left(\operatorname{Trp}^{+}\right.$; Gietz \& Sugino, 1988) to construct pCaRAM2-1. Plasmid pCaRAM2T was constructed by ligating the CaRAM2 insert from PCR clone pCaRAM2-22 into KpnI/ PstI-digested YEplac112. The CaCDC43 insert of PCR clone pCaCDC43-40 was subcloned into EcoRI/SalI-digested pRS426 (Ura ${ }^{+}$; Christianson et al., 1992) to construct p40CDCU and the same fragment from both pCaCDC43-43 and pCaCDC43-40 was subcloned into pRS423 $\left(\mathrm{His}^{+}\right.$; Christianson et al., 1992) to construct p43CDC and p40CDC, respectively.

Complementation of S. cerevisiae GGTase I mutants with $\mathbf{C}$. albicans subunits. The $S$. cerevisiae ts mutants RS51-3A (ram2) and CJ198-2B (cdc43) were first transformed to $\mathrm{Trp}^{+}$ with either CaRAM2 plasmids pCaRAM2-1 and pCaRAM2T or empty vector YEplac112. Transformation was as described by Elble (1992). The transformants were subsequently transformed to $\mathrm{Ura}^{+}$with either $\mathrm{CaCDC} 43$ plasmids pCaCDC7 and $\mathrm{p} 40 \mathrm{CDCU}$ or their respective vector controls YEp24 and pRS426. Transformants selected at $30^{\circ} \mathrm{C}$ were tested for complementation at $37^{\circ} \mathrm{C}$.

A $S$. cerevisiae ram 2 disruptant was also tested for complementation and was constructed as follows. First, the $S$. cerevisiae RAM2 gene was amplified by PCR from genomic DNA of strain S288C with primers $5^{\prime}$ GCGCCGCTCGAGTTGTGATTAGTCGGTTAGAGG $3^{\prime}$ and $5^{\prime}$ CGGTGGCTCGAGGGGTTTGGACGCATCAATGAT 3' (underlined sequences are $X h o l$ sites). The PCR reaction $(50 \mu l$ volume) contained $100 \mathrm{ng}$ genomic DNA, $1 \cdot 0 \mu \mathrm{M}$ each primer, $200 \mu \mathrm{M}$ each dNTP, 1 unit Elongase and $1 \times$ buffers $A$ and $B$ (GibcoBRL). The cycle profile $\left(35\right.$ cycles) was $95^{\circ} \mathrm{C}$ for $1 \mathrm{~min}$, $55^{\circ} \mathrm{C}$ for $1 \mathrm{~min}, 72{ }^{\circ} \mathrm{C}$ for $1.5 \mathrm{~min}$, followed by one cycle at $72{ }^{\circ} \mathrm{C}$ for $10 \mathrm{~min}$. The $1566 \mathrm{bp}$ PCR product was cloned into the $X$ hol site of pRS423 $\left(\mathrm{His}^{+}\right.$) to construct pRAM2-31. The RAM2 Xhol fragment from pRAM2-31 was subsequently cloned into pGEM5Zf( + ) to construct pFTA1 and into YEplac195 (Ura ${ }^{+}$; Gietz \& Sugino, 1988) to construct pFTA4. An insertion-deletion of RAM2 was made by replacing the $0.5 \mathrm{~kb} \mathrm{BglII}-E c o$ RI fragment of pFTA1 with a $0.8 \mathrm{~kb} B g l \mathrm{II}-$ EcoRI TRP1 fragment from pJJ246 (Jones \& Prakash, 1990) to construct pFTA1d. Trp ${ }^{+}$transformants of diploid W303 were obtained with a HincII-SphI fragment of pFTA1d containing the RAM2 disruption and Southern blot analysis confirmed that a gene replacement had taken place on one allele in several transformants. Since we expected a haploid $\mathrm{ram} 2$ disruptant to be lethal as reported in the literature (He $e t$ al., 1991), one diploid heterozygous for the disruption was transformed with either the URA3 RAM2 plasmid pFTA4 or 
control vector YEplac195. Subsequently, the transformants were sporulated and tetrads dissected. Three tetrads in which all four spores were viable were obtained from the dissection of a Ura ${ }^{+}$RAM2 transformant and a transformant containing vector YEplac195 yielded tetrads which contained only two viable spores, consistent with the disruption of an essential gene. Three four-spore tetrads from a $\mathrm{Ura}^{+} \mathrm{RAM} 2$ transformant were propagated on 5-fluoroorotic acid (5-FOA)containing medium (Boeke et al., 1984) to select against the RAM2 Ura ${ }^{+}$plasmid, and on SD medium supplemented with uracil. All four segregants from the three tetrads grew on the control medium while only two of the four spores grew on the 5-FOA-containing medium; the spores which did not grow on 5 -FOA medium were nonviable upon loss of the RAM2 plasmid and therefore contained the ram 2 disruption. The $\mathrm{Ura}^{+}$RAM2 transformant of one of the latter spores, designated W303dR2, was chosen for complementation studies.

$\mathrm{Leu}^{+} \mathrm{His}^{+}$transformants of ram 2 disruptant W303dR2 were obtained with pCaRAM2-22 and either p43CDC or p40CDC and appropriate vector controls. The transformants were streaked onto minimal medium at $30^{\circ} \mathrm{C}$ and subsequently grown overnight in YPAD broth. The strains were plated on 5FOA-containing medium and incubated at $30^{\circ} \mathrm{C}$.

\section{RESULTS}

\section{Purification of C. albicans GGTase I}

GGTase I and FTase activities were detected in cell-free extracts of $C$. albicans in protein prenyltransferase assays containing ${ }^{3} \mathrm{H}-\mathrm{GGPP}$ and a typical GGTase I prenyl acceptor, Ras-CAIL, or ${ }^{3} \mathrm{H}$-FPP and a typical FTase prenyl acceptor, Ras-CVLS, respectively (data not shown). Interestingly, both the GGTase I and FTase activities were elevated approximately 10 - to 15 -fold following clarification of the supernatant by ultracentrifugation (Table 1), perhaps resulting from removal of inhibiting lipids or some other membrane associated factor. Fractionation by anion exchange afforded the resolution of a single peak of GGTase I activity and a single major peak of FTase activity (Fig. 1a). GGTase I was purified to near homogeneity by additional con- ventional chromatographic steps as described in Methods. Purification results from a typical preparation of GGTase I are presented in Table 1. The purification enriched two polypeptides migrating at approximately $45 \mathrm{kDa}$ and $41 \mathrm{kDa}$ by SDS-PAGE (Fig. 1b) and the protein size, estimated as approximately $65 \mathrm{kDa}$ by gel filtration, suggests that CaGGTase I exists as an $\alpha / \beta$ heterodimer. Internal peptide sequences were obtained for both subunits (see Methods) and sequence comparisons to the $S$. cerevisiae GGTase I subunits, Ram2p and Cdc43p, revealed homology with peptide sequences from the $41 \mathrm{kDa}$ and $45 \mathrm{kDa}$ subunits, respectively, suggesting that the C. albicans GGTase I homologue had been purified.

\section{Characterization of C. albicans GGTase I}

Detergent was absolutely required to maintain the solubility of the GGPP substrate in the enzyme assay and dodecyl maltoside or Triton X-100 $(0.02-0.05 \%)$ were found to be satisfactory for maintaining substrate solubility and enzyme activity. Initial assays were performed with Ras-CAIL in the absence of DTT, and under these conditions a $\mathrm{pH}$ optimum of 9 was observed. The addition of DTT $(1-10 \mathrm{mM})$ was found to be inhibitory at alkaline $\mathrm{pH}$, and was routinely omitted until it was subsequently discovered that DTT shifted the $\mathrm{pH}$ optimum to $7 \cdot 5-8$ (data not shown). The effect of DTT resulted from stimulation of enzyme activity at the lower $\mathrm{pH}$ and inhibition at higher $\mathrm{pH}$. For example, with RAS-CVIL at $\mathrm{pH} 7.5$ in the presence and absence of $5 \mathrm{mM}$ DTT, the relative activities observed were $100 \%$ and $45 \%$, respectively, while at $\mathrm{pH} 9$ the activities observed were $38 \%$ and $78 \%$, respectively. The DTT dependence of the $\mathrm{pH}$ optimum was observed with both Ras-CAIL and Ras-CVIL. Metal requirements for $C$. albicans GGTase I were also examined (Fig. 2) since all previously characterized prenyltransferases are magnesium-dependent, zinc metalloenzymes, with the apparent exception of mammalian GGTase I which has been reported to require only zinc (Zhang \& Casey,

Table 1. Purification of C. albicans GGTase I

\begin{tabular}{|lccccc|}
\hline Sample & $\begin{array}{c}\text { Protein } \\
(\mathbf{m g})\end{array}$ & $\begin{array}{c}\text { Specific activity } \\
\left(\mathbf{u n i t s} \mathbf{~ m g}^{-1}\right)^{*}\end{array}$ & $\begin{array}{c}\text { Total } \\
\text { activity } \\
(\text { units })^{*}\end{array}$ & $\begin{array}{c}\text { Purification } \\
\text { (-fold) }\end{array}$ & $\begin{array}{c}\text { Recovery } \\
(\%)\end{array}$ \\
\hline Homogenate & 1647 & $0 \cdot 44$ & 725 & - & - \\
100000 $g$ supernatant & 825 & $7 \cdot 4$ & 6110 & 1 & 100 \\
Q-Sepharose & 39 & 145 & 5660 & 20 & 93 \\
Phenyl-Sepharose & $6 \cdot 1$ & 714 & 4360 & 96 & 71 \\
S-200 10/30 HR & $0 \cdot 062 \dagger$ & 48000 & 2960 & 6500 & 48 \\
Mono-Q 5/5 HR & $0 \cdot 01 \dagger$ & 183000 & 1800 & 24700 & 29 \\
\hline
\end{tabular}

* 1 unit is defined as 1 pmol $\left.{ }^{3} \mathrm{H}\right]$ GGPP transferred to Ras-CVIL $\min ^{-1}$ (assay conditions: $50 \mathrm{mM}$ Bistris propane, $\mathrm{pH} 9,10 \mathrm{mM} \mathrm{MgCl}_{2}$, $0.1 \mathrm{mM} \mathrm{ZnCl}, 20 \mu \mathrm{M}$ Ras-CVIL, $2-4 \mu \mathrm{M}{ }^{3} \mathrm{H}$-GGPP, $0.05 \%$ dodecyl maltoside, $30^{\circ} \mathrm{C}$ ).

†Protein determined with Protein-Gold assay. 
(a)

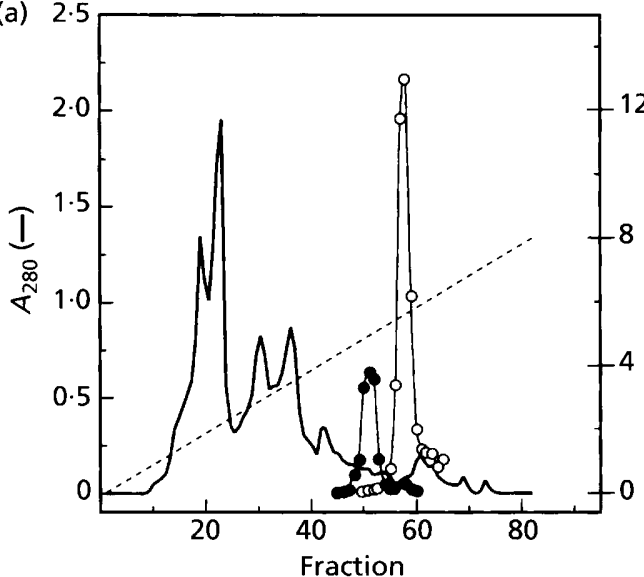

I

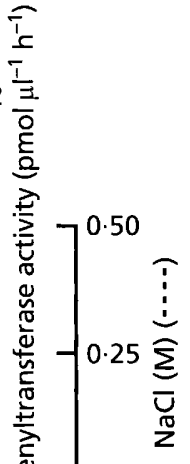

(b)

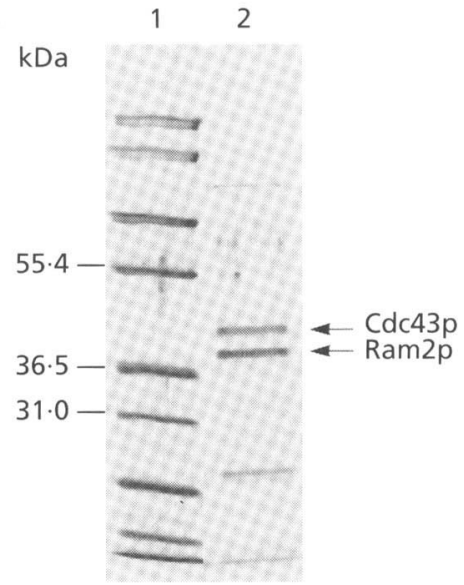

Fig. 1. (a). Separation of GGTase I and FTase activities by anion exchange on Q-Sepharose HP. Chromatographic conditions are described in Methods and the sample load and recovery are reported in Table 1 . Portions $(10 \mu l)$ of the indicated fractions were assayed for GGTase I (O) and FTase (O) activities as described in Table 1 and Methods, respectively. The entire column profile had been assayed in prior preparations and no significant prenyltransferase activity was detected other than what is indicated. (b) Subunit composition of the purified C. albicans GGTase I. A sample $(2.5 \mu \mathrm{l} ; 25 \mathrm{ng})$ of the Mono-Q-purified GGTase I (lane 2) was subjected to SDS-PAGE and the protein bands visualized by silver staining. Lane 1 contains molecular mass standards (Mark12, Novex).

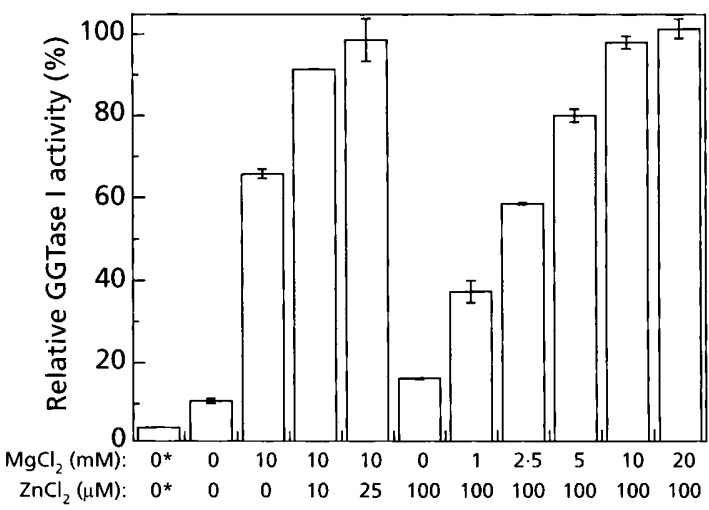

Fig. 2. Zinc and magnesium dependence of $C$. albicans GGTase I. Purified GGTase I was assayed for activity in the presence of the indicated final concentrations of $\mathrm{ZnCl}_{2}$ and $\mathrm{MgCl}_{2}$. Assays were performed in $50 \mathrm{mM}$ HEPES, pH 7.5, $5 \mathrm{mM}$ DTT, $0.02 \%$ Triton X-100, containing $25 \mu \mathrm{M}$ Ras-CVIL and $0.25 \mu \mathrm{M}{ }^{3} \mathrm{H}-\mathrm{GGPP}$. Data in the lane marked with asterisks $\left(^{*}\right)$ were obtained from an assay which also contained $2.5 \mathrm{mM}$ EDTA. The data are means of duplicate determinations; error bars indicate the difference between replicates.

1996b). Purified GGTase I was nearly inactive in the absence of added zinc and magnesium salts, and the residual activity was further reduced by the addition of $2.5 \mathrm{mM}$ EDTA. In contrast to mammalian GGTase I, the addition of $100 \mu \mathrm{M} \mathrm{ZnCl}$, alone restored only $15 \%$ of full enzyme activity. Full activity required the further addition of $10-20 \mathrm{mM} \mathrm{MgCl}$, which stimulated the zinc-containing enzyme an additional sevenfold. The addition of $10 \mathrm{mM} \mathrm{MgCl}$ alone restored $65 \%$ of full activity. Full activity was achieved by the further addition of $10 \mu \mathrm{M} \mathrm{ZnCl}_{2}$, suggesting that the purified enzyme maintained a significant amount of bound zinc. Michaelis constants $\left(K_{m}\right)$ were determined for RasCVIL and GGPP as $23 \mu \mathrm{M}$ and $0.024 \mu \mathrm{M}$ (means of two determinations) respectively, by fitting plots of initial velocity $(\mathrm{pH} 7.5)$ versus substrate concentration to the Michaelis-Menten equation by non-linear regression analysis (data not shown). Approximate $K_{\mathrm{m}}$ values of $110 \mu \mathrm{M}$ and $90 \mu \mathrm{M}$ were obtained for Ras-CAIL and Ras-CTIL, respectively.

\section{Substrate preferences of C. albicans GGTase I and FTase}

The prenyl acceptor substrate specificity of FTase and GGTase I is a critical issue regarding the functional requirement for GGTase I in C. albicans. FTase crossspecificity for typical GGTase I substrates could obviate the presumed requirement for the latter. Therefore, the substrate specificity of the partially purified GGTase I and FTase activities was examined with a series of RasCaaX homologues as the prenyl acceptor and either GGPP or FPP as the prenyl donor (Fig. 3). The CaaX sequences used included CVIL (Candida CRL1; RHO homologue), CVVL (Candida RHO1), CTIL (Candida CDC42), CAIL, CVLM, CVLS and CVIA (S. cerevisiae a mating factor). GGTase I showed a preference for typical GGTase I CaaX prenyl acceptor substrates where $\mathrm{X}$ is a leucine residue and showed almost complete selectivity for GGPP as the prenyl donor (Fig. 3a). Within the Ras-CaaL series the ranking of GGTase I activity was CVIL $>$ CTIL $>$ CAIL $\sim$ CVVL. Modest activity was observed with CVLM and no activity was observed with CVLS or CVIA, typical acceptor substrates for FTase. FTase exhibited a strong preference for Ras-CaaX ending with methionine (CVLM) and showed much less activity with other typical FTase 

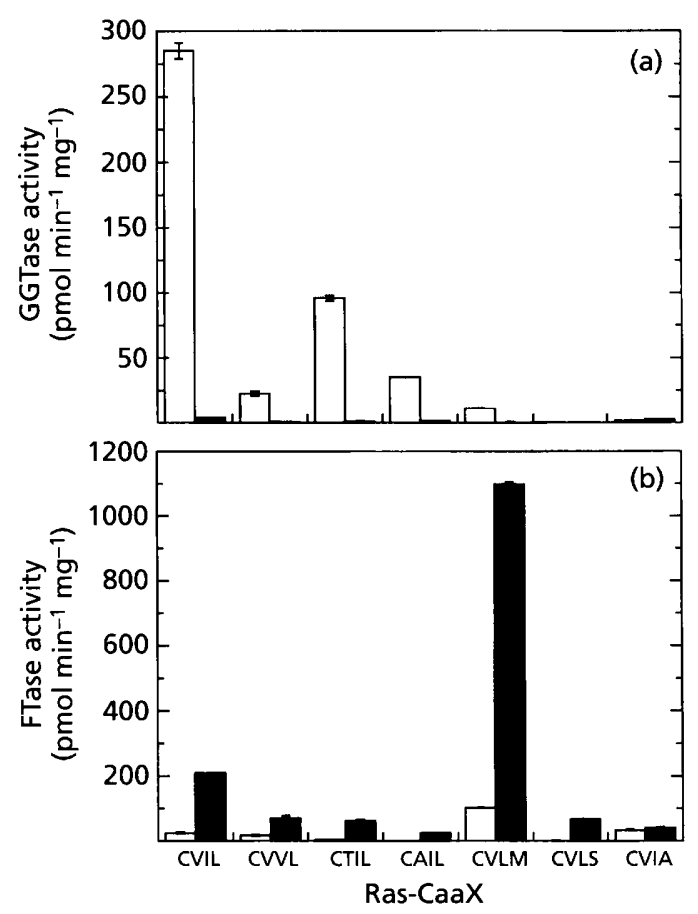

Fig. 3. Prenyl acceptor substrate specificity of $C$ albicans GGTase I (a) and FTase (b). GGTase I and FTase activities were separated by the first two columns (Q-Sepharose and PhenylSepharose) as described in Methods and assayed with the indicated Ras-CaaX substrate $(20 \mu \mathrm{M})$ and either GGPP $(\square)$ or FPP (四) at $4 \mu \mathrm{M}$. All assays were performed at $\mathrm{pH} 7.5$ as described in Methods, and included $1 \mathrm{mM}$ DTT. The data are means of duplicate determinations; error bars indicate the difference between replicates.

acceptors examined (CVLS and CVIA) (Fig. 3b). FTase was also observed to catalyse some farnesylation of all CaaL substrates examined. The ranking for FTase farnesylation of the CaaL series was CVIL $>$ CVVL CTIL > CAIL and occurred with an efficiency of 19 , 6,6 and $2 \%$, respectively, relative to farnesylation of Ras-CVLM. The enzyme samples used in this experiment were both partially purified by anion exchange and hydrophobic interaction chromatography (see Methods) and purified to a similar extent (approx. 100- fold). A comparison of the specific activity data in Fig. 3 indicates that FTase-catalysed farnesylation of CaaL substrates occurs at a level similar to that of GGTase I-catalysed geranylgeranylation.

\section{Cloning of CaRAM2 and CaCDC43 from C. albicans}

Purification and sequencing of the protein subunits allowed for isolation of gene fragments by PCR as described in Methods. A 729 bp CaR AM2 PCR product contained an open reading frame exhibiting approximately $37 \%$ sequence identity to the S. cerevisiae RAM2 $(\alpha$-subunit) protein sequence and a $573 \mathrm{bp} \mathrm{CaCDC43}$ PCR product was found to contain an ORF exhibiting approximately $29 \%$ identity to the $S$. cerevisiae CDC43 protein sequence ( $\beta$-subunit).

The PCR clones of each gene were then used to isolate genomic clones and the DNA and predicted peptide sequences of each subunit were determined. Open reading frames of 918 and $1194 \mathrm{bp}$ encoding putative peptides of 306 and 398 amino acids were identified for CaRAM2 and $\mathrm{CaCDC} 43$, respectively. The predicted molecular masses for $\mathrm{CaRam} 2 \mathrm{p}$ and $\mathrm{CaCdc} 43 \mathrm{p}$ were 36.9 and $47.8 \mathrm{kDa}$, respectively, which agreed reasonably well with the determinations for the purified subunits. All of the peptide sequences determined from the purified C. albicans GGTase I subunits were found in $\mathrm{CaCdc} 43 \mathrm{p}$ and $\mathrm{CaRam} 2 \mathrm{p}$, confirming that the genes isolated corresponded to the purified proteins. CaRam2p and $\mathrm{CaCdc} 43 \mathrm{p}$ are 42 and $34 \%$ identical to their corresponding $S$. cerevisiae homologues, respectively, and 61 and $55 \%$ similar, as summarized in Table 2 . Both C. albicans subunits are approximately $30 \%$ identical to their mammalian, plant and Schizosaccharomyces pombe homologues.

One CUG codon, which is decoded in vivo as serine in C. albicans instead of the conventional leucine (Tuite \& Santos, 1996), was identified near the C-terminus of Cdc43p encoding amino acid 388. A direct repeat of the trinucleotide ACT/C/G (the third nucleotide is most frequently $\mathrm{T}$ ) was found 72 nucleotides upstream of the coding sequence of $\mathrm{CaCDC} 43$ and was repeated 22

Table 2. Comparisons of amino acid sequences of $C$. albicans GGTase I subunits with GGTase I of other organisms

\begin{tabular}{|llcll|}
\hline \multirow{2}{*}{ Organism } & \multicolumn{2}{c}{ CaRam2p } & & \multicolumn{2}{c|}{ CaCdc43p } \\
\cline { 5 - 6 } \cline { 5 - 5 } & Identity $(\%)$ & Similarity (\%) & Identity (\%) & Similarity (\%) \\
\hline S. cerevisiae & 42 & 61 & 34 & 55 \\
Sch. pombe & 36 & 46 & 30 & 53 \\
Human & 30 & 58 & 30 & 53 \\
Rat & 30 & 57 & 29 & 54 \\
Bovine & 30 & 57 & NA & NA \\
Tomato & 29 & 55 & NA & NA \\
\hline
\end{tabular}

NA, Not available. 
(a)

\begin{tabular}{|c|c|}
\hline & 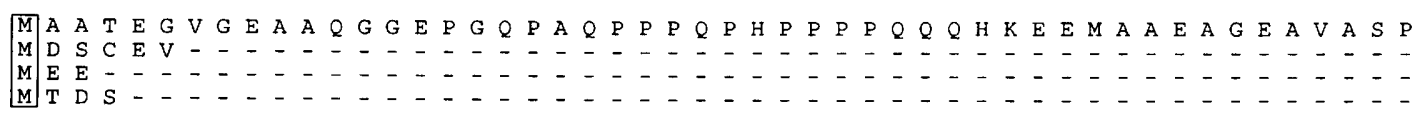 \\
\hline & 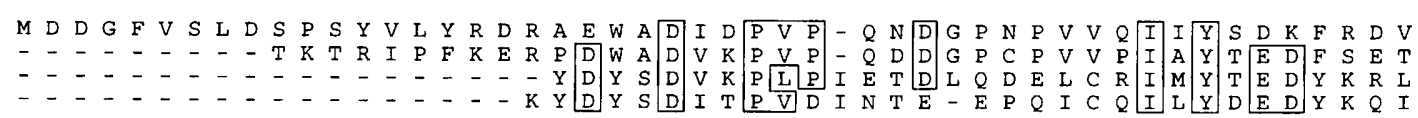 \\
\hline & 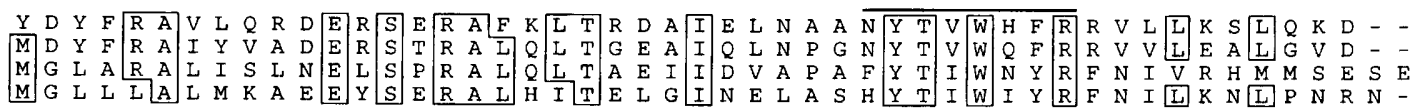 \\
\hline & 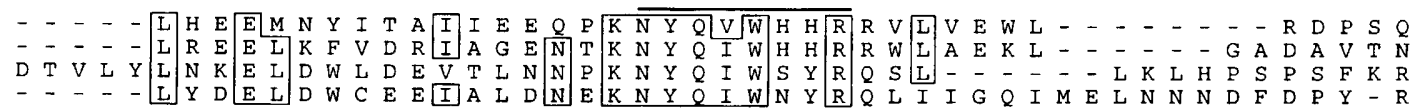 \\
\hline & 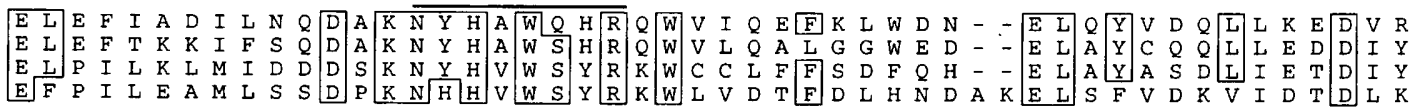 \\
\hline iae & 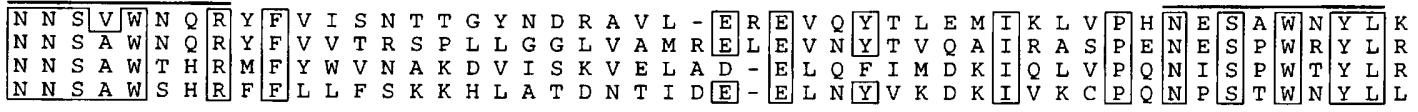 \\
\hline & 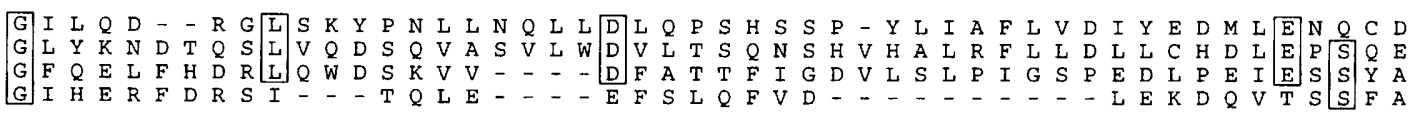 \\
\hline & 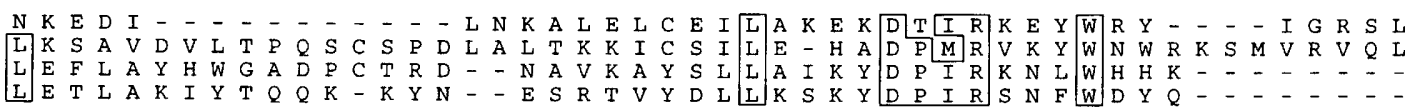 \\
\hline & $\mathrm{L}$ \\
\hline
\end{tabular}

(b)

\begin{tabular}{|c|c|}
\hline & 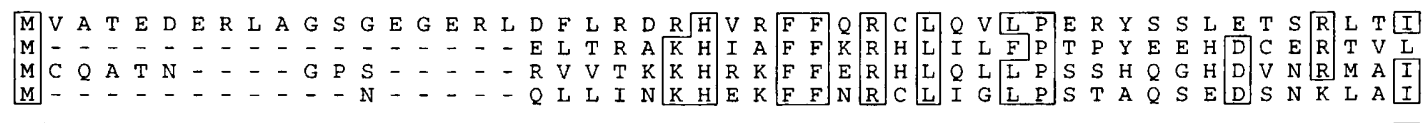 \\
\hline be & 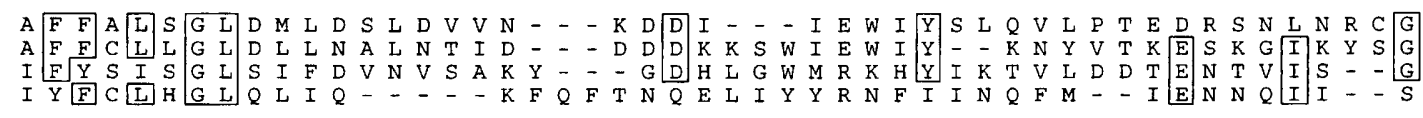 \\
\hline $\begin{array}{l}n \\
\text { abe } \\
\text { evisiae } \\
\text { cans }\end{array}$ & 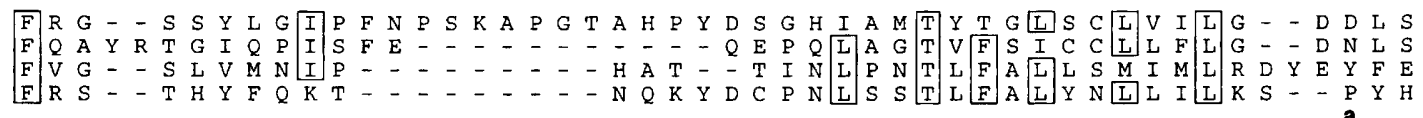 \\
\hline $\begin{array}{l}\text { nan } \\
\text { ombe } \\
\text { erevisiae } \\
\text { libicans }\end{array}$ & 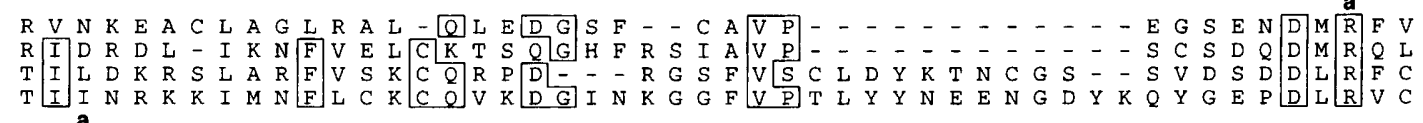 \\
\hline & 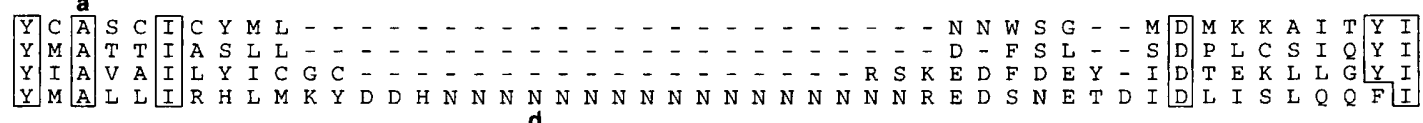 \\
\hline $\begin{array}{l}\text { nan } \\
\text { ombe } \\
\text { erevisiae } \\
\text { lbicans }\end{array}$ & 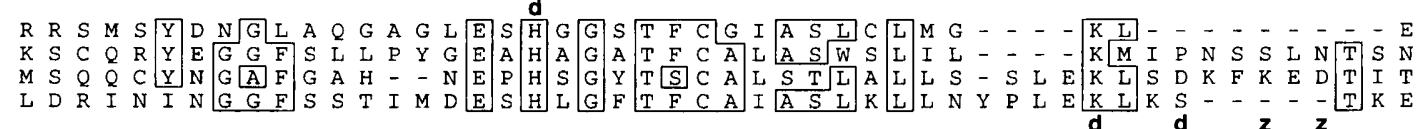 \\
\hline siae & 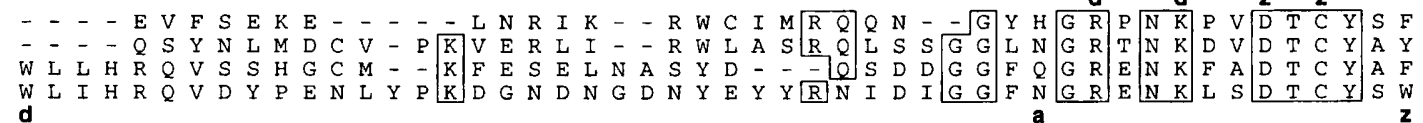 \\
\hline $\begin{array}{l}\text { bisiae } \\
\text { ans }\end{array}$ & 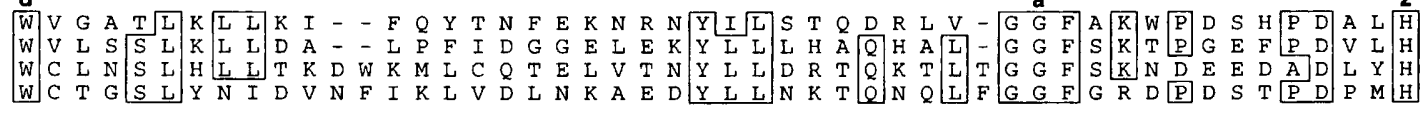 \\
\hline & 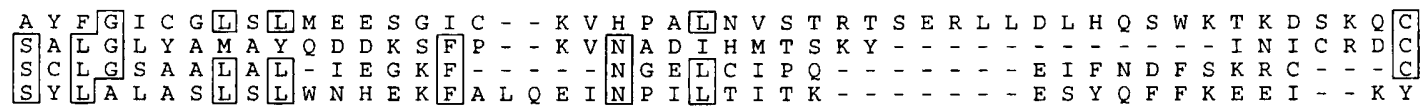 \\
\hline $\begin{array}{l}\text { e } \\
\text { isiae } \\
\text { ns }\end{array}$ & \\
\hline
\end{tabular}

Fig. 4. For legend see facing page. 
times. The significance of this repeat in CaCDC43 is unknown, but it may play a regulatory role. A BLAST search revealed similar sequences in $5^{\prime}$ and $3^{\prime}$ noncoding regions of other genes as well as in centromeric DNA of $S$. cerevisiae and Sch. pombe. The 3' untranslated region of $C a C D C 43$ contains the $S$. cerevisiae consensus sequence for transcription termination TAG... TAGT....TTT described by Zaret \& Sherman (1982) beginning at nucleotide 1671 . Three potential TATA boxes were noted in the $5^{\prime}$ noncoding region of CaRAM2.

A multiple sequence alignment of the $\alpha$-subunit (Ram2p) from yeast, human and a plant (Fig. 4a) revealed that CaRam2p contains several small regions of homology including five sequence repeats previously noted for prenyltransferase $\alpha$-subunits. The first three of these regions are a close match to the consensus sequence motif NYxxWxYR ( $\mathrm{x}$ is an undefined amino acid; Boguski et al., 1992) while the latter two repeats differ by two amino acids. From the rat FTase crystal structure this motif is known to occur in $\alpha$-subunit 'helical hairpins' which form part of the $\beta$-subunit interface (Park \& Beese, 1997).

Fig. 4 (b) presents a multiple sequence alignment for the $\beta$-subunit (Cdc43p). A unique feature of $\mathrm{CaCdc} 43 \mathrm{p}$ is an insertion of a tract of 17 asparagines at amino acid 178 . The putative polyasparagine tract of $\mathrm{CaCdc} 43 \mathrm{p}$ is encoded by an AT-rich region resembling noncoding sequence, but is most probably translated. No good matches to intron consensus sequences were found and introns occur infrequently in C. albicans genes. Three residues which are completely conserved in all $\beta$-subunits of GGTase I, Asp 302, Cys 304 and His 357, are putatively assigned as the $\mathrm{CaCdc} 43 \mathrm{p} \beta$-subunit zinc ligands based on comparison to the FTase crystal structure (Park et al., 1997). Several residues implicated in substrate (prenyl donor and acceptor) binding by mutagenesis studies of FTase (Kral et al., 1997) or GGTase I (Ohya et al., 1996) and the FTase crystal structure (Park \& Beese, 1997) are conserved in all $\beta$ subunits of GGTase I including $\mathrm{CaCdc} 43 \mathrm{p}$ and are indicated in Fig. 4(b).

\section{Allelic and strain variations are found in both subunits of C. albicans GGTase I}

PCR clones containing the coding region of each subunit and various amounts of flanking sequence were isolated from strain CAI4, the strain most routinely used for Candida genetics, and from MY1055, a pathogenic strain that we use in mouse models for virulence. The (a)

$\begin{array}{lllllllllllllllllllllllll}\text { CA124 } & Y & D & D & H & N & N & N & N & N & N & N & N & N & N & N & N & N & N & N & N & N & R & E & D \\ \text { MY1055-14 } & Y & D & D & . & N & N & N & N & N & N & N & N & . & . & . & . & . & . & . & . & . & R & E & D \\ \text { MY1055-24 } & Y & D & D & . & N & N & N & N & N & N & N & N & . & . & . & . & . & . & . & . & . & R & E & D \\ \text { CAI4-40 } & Y & D & D & . & N & N & N & N & N & N & . & . & . & . & . & . & . & . & . & . & . & R & E & D \\ \text { CAI4-43 } & Y & D & D & . & N & N & N & N & N & N & N & N & N & N & N & N & N & . & . & . & . & R & E & D\end{array}$

(b)

CA124

MY1055-14

MY1055-24

CAI $4-40$

CAI $4-43$

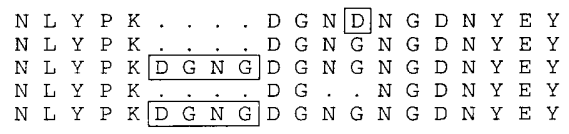

Fig. 5. (a, b) Two divergent regions among CaCdc43ps. CA124, MY1055 and CAI4 are different C. albicans strains. MY1055-14 and -24 and CAI4-40 and -43 represent different alleles.

predicted amino acid sequences of $\mathrm{CaCdc} 43 \mathrm{ps}$ from CAI4 and MY1055 differed substantially from Cdc43p of CA124 in two regions. The most notable difference is the large variation in the number of asparagines and the absence of a histidine residue directly preceding the asparagine tract in the predicted translation products of CAI4 and MY1055 (Fig. 5a). The strains differ at another repetitive region of the protein : approximately 80 amino acids downstream of the asparagine tract, one allele of both CAI4 and MY1055 encodes an insertion of 'DGNG' (Fig. 5b). CAI4-40 contains a deletion of ' ND' and the other alleles have a $D(277) G$ change. Four additional changes compared to Cdc43p of CA124 were noted throughout the protein. One was an $\mathrm{E}(395) \mathrm{K}$ change in three out of four alleles analysed whereas the other changes were only found in one of the alleles. Fewer differences were found in the predicted Ram2 polypeptides. One allele from CAI4 encoded no changes compared to CA124 while the other allele had one silent base change. Likewise, one allele of MY1055 was identical to CA124 whereas the other contained four base changes and encoded a single $\mathrm{D}(155) \mathrm{G}$ change.

\section{Complementation of a S. cerevisiae ts cdc43 mutant requires both CaCDC43 and CaRAM2}

Complementation of the $t s$ defect of $S$. cerevisiae $c d c 43$ and ram 2 mutants, CJ198-2B and RS51-3A, respectively, was attempted by coexpression of both subunits of $C$. albicans GGTase I. The C. albicans GGTase I subunit genes from strains CA124 or CAI4 were expressed under their respective $C$. albicans promoters on high-copy $S$. cerevisiae plasmids. The $t s$ defect of the $c d c 43$ mutant was complemented in transformants containing both subunits as shown in Fig. $6 ; 13$ and 9 transformants

Fig. 4. Amino acid sequence alignments of protein geranylgeranyl transferase $\alpha$ (a) and $\beta$ (b) subunits. Alignments were determined by the CLUSTAL program. Amino acid identities are indicated by boxes. Dashes denote gaps formed by the alignment algorithm. (a) The five regions matching the consensus ' $N Y x x W x Y R^{\prime}$ are marked by bars above the sequence. The GenBank accession numbers for the sequences of the GGTase I $\alpha$ subunits are as follows: C. albicans CaRAM2, AF110691; S. cerevisiae RAM2, M88584; tomato LeFTA, U83707; and human $\alpha$, L00634. (b) Residues implicated in zinc, prenyl acceptor and prenyl donor binding are indicated by the superscripts $z$, $a$, d, respectively. The GenBank accession numbers for the aligned sequences of the $\beta$ subunits of GGTase I are as follows: $C$. albicans CaCDC43, AF110690, S. cerevisiae CDC43, M31114; human $\beta$, L25441; S. pombe Cwg2+, Z12155. 

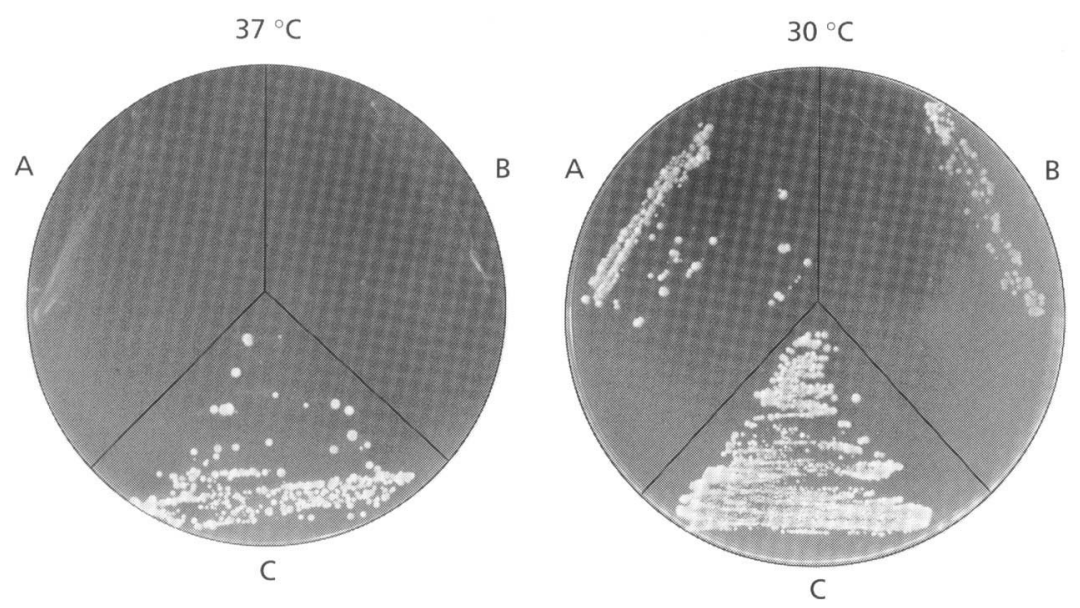
Fig. 6. Complementation of the ts defect of S. cerevisiae cdc43 mutant CJ198-2B by CaCDC43 and CaRAM2. CJ198-2B was transformed with: $A$, vectors pRS426 and Yeplac112; B, p40CDCU (CaCDC43) and Yeplac112; and $C_{1}$ p40CDCU (CaCDC43) and pCaRAM2T (CaRAM2).

containing both $\mathrm{CaCDC} 43$ and CaRAM2 from CA124 and CAI4, respectively, grew at the nonpermissive temperature. Transformants containing $\mathrm{CaCDC} 43$ alone were not viable at the restrictive temperature. No complementation of the ts ram 2 mutant was obtained with both CaCDC43 and CaRAM2 (tested from CA124 only) for nine transformants tested at the nonpermissive temperature.

The $S$. cerevisiae ts ram 2 mutant is defective in FTase as well as GGTase I at the nonpermissive temperature since the $\alpha$ subunit encoded by RAM 2 is common to both GGTase I and FTase. The lack of complementation by both subunits of C. albicans GGTase I is most probably due to nonfunctional FTase since we were able to complement the $t s$ defect of the $c d c 43$ mutant. FTase of $S$. cerevisiae is essential at $37^{\circ} \mathrm{C}$ but not at $30^{\circ} \mathrm{C}$ as $S$. cerevisiae GGTase I compensates for FTase at $30^{\circ} \mathrm{C}$ (Ohya et al., 1993; Trueblood et al., 1993). We tested to see if the lethality of a $S$. cerevisiae ram 2 disruptant could be corrected by coexpression of the C. albicans GGTase I subunits at $30^{\circ} \mathrm{C}$. We expected that the GGTase I defect of the ram2 disruptant strain, W303dR2, would be corrected by the C. albicans enzyme and we wanted to know if C. albicans GGTase I would compensate for FTase as well. We used the 'plasmid shuffle technique' to determine if the C. albicans GGTase I subunits expressed under their respective promoters in the ram2 disruptant strain W303dR2 would allow loss of the $\mathrm{Ura}^{+}$RAM2 plasmid. To select against the $\mathrm{Ura}^{+}$plasmid containing the $S$. cerevisiae RAM2 gene, transformants containing the C. albicans genes were subsequently propagated at $30{ }^{\circ} \mathrm{C}$ on medium containing 5-FOA. No 5-FOA-resistant colonies were obtained, indicating that it was not possible to maintain viability upon loss of the $S$. cerevisiae URA3 RAM2 plasmid.

\section{DISCUSSION}

We have purified the C. albicans GGTase I protein and isolated and sequenced the genes (CaRAM2 and $\mathrm{CaCDC43)}$ encoding the heterodimeric enzyme. The functionality of the cloned $C$. albicans GGTase I subunits was confirmed by coexpression under their native promoters in a $S$. cerevisae ts $c d c 43$ mutant which enabled growth at the nonpermissive temperature. Complementation was not obtained by expression of $C D C 43$ alone, suggesting that heterodimers between the S. cerevisiae $\alpha$ and C. albicans $\beta$ subunits of GGTase I are either not functional or not formed. This result explains our earlier failure to clone $\mathrm{CaCDC} 43$ by complementation of the $t s c d c 43$ mutant (data not shown). Similarly, Yalovsky et al. (1997) have shown that coexpression of both the $\alpha$ and $\beta$ subunits of tomato FTase was required to complement the $t s$ defect of a $S$. cerevisiae ram 1 mutant. It is also noteworthy that the $C$. albicans subunits functioned in $S$. cerevisiae despite the presence of a CUG codon in CaCDC43 which is usually translated as serine in C. albicans instead of leucine. However, we were unable to detect any increase in GGT ase I activity in cell-free extracts prepared from the cdc43 mutant complemented with $\mathrm{CaCDC} 43$ and CaRAM2 (data not shown). The extracts were made from cells grown at $30^{\circ} \mathrm{C}$ and assayed at $30^{\circ} \mathrm{C}$, where we detected a low level of $S$. cerevisiae GGTase I activity (3-5\% of wild-type) from the $c d c 43$ mutant control, as previously reported (Ohya et al., 1996). While poor expression of the C. albicans genes or poor in vitro enzyme activity with the Ras-CVIL or Ras-CAIL substrates (high $K_{m}$ values) could explain our inability to detect CaGGTase I activity, presumably the critical ScRho1 and ScCdc42 proteins are being adequately geranylgeranylated in the whole cell.

Correction of the growth defects of the $S$. cerevisiae ram 2 mutants requires restoration of both GGTase I and FTase activity, as the $\alpha$ subunit encoded by RAM 2 is common to both GGTase I and FTase. FTase is essential for survival of $S$. cerevisiae at $37^{\circ} \mathrm{C}$ but is not required at $30^{\circ} \mathrm{C}$. Since the $\mathrm{C}$. albicans subunits complemented the $t$ s GGTase I mutant, the inability to complement the ts ram 2 mutant suggests that the FTase defect has not been corrected and that heterodimers between C. albicans Ram $2 \mathrm{p}$ and S. cerevisiae Ram $1 \mathrm{p}$ are probably not functional or do not form. The lack of complementation of the ram 2 disruptant at $30^{\circ} \mathrm{C}$ is most probably due to defective FTase as well. All of 
these experiments suggest that C. albicans GGTase I expressed from its native promoters in S. cerevisiae can compensate for defective GGTase I, but cannot additionally substitute for S. cerevisiae FTase. It is possible that greater expression of the C. albicans GGTase I subunits, i.e. under $S$. cerevisiae promoters, would rescue the ram 2 null mutant. Expression in $S$. cerevisiae might also be improved by mutating the CUG codon encoding amino acid 388 of Cdc43p to encode serine. Alternatively, C. albicans GGTase I may exhibit tighter prenyl acceptor (CaaX) specificity than $S$. cerevisiae GGTase I and may be incapable of sufficiently prenylating the requisite $\mathrm{Ras}$ proteins (Ras $1=\mathrm{CIIC}$; Ras $2=$ CIIS). This possibility is consistent with the observed inability of C. albicans GGTase I to geranylgeranylate RasCVLS.

A striking feature of $\mathrm{CaCdc} 43 \mathrm{p}$ is an insertion of a tract of asparagines at amino acid 178 that is not found in other prenyltransferases and whose length varies among strains and between alleles. Several proteins from Dictyostelium discoideum contain translated polyasparagine tracts and similar tracts have been identified in at least two S. cerevisiae proteins, Swh1p and Abf1p (Diffley \& Stillman, 1989; Schmalix \& Bandlow, 1994). The function of the polyasparagine tracts is unknown and the significance, if any, of this region in $\mathrm{CaCdc} 43 \mathrm{p}$ remains to be determined. We do know that $\mathrm{CaCdc} 43 \mathrm{p}$ containing either 6 or 17 asparagines is functional, as complementation of the $t s c d c 43$ mutant was obtained with either of these homologues. Restriction site polymorphisms between alleles of C. albicans have been identified previously (Kelly et al., 1987), but to our knowledge, this is the first time that differences between the coding sequence of two alleles has been documented. It will be interesting to see what other types of changes occur between ORFs of different alleles and how frequently this occurs when more sequence of the $C$. albicans genome becomes available.

Studies on the substrate specificity of $S$. cerevisae GGTase I and FTase have shown that prenyl acceptor specificity is largely defined by the C-terminal X-residue of the CaaX motif and, moreover, is largely independent of the remaining $\mathrm{N}$-terminal protein sequence (Moores et al., 1991). S. cerevisiae GGTase I has a preference for $\mathrm{CaaX}$ substrates ending in leucine and to a lesser extent, methionine, while $S$. cerevisiae FTase preferentially farnesylates $\mathrm{CaaX}$ sequences ending in methionine, serine, cysteine and alanine. Enyzme specificity studies with recombinant yeast FTase from $S$. cerevisiae have in fact shown Ras-CaaL substrates to be modestly farnesylated $(3-8 \%)$ relative to Ras-CAIM (Caplin et al., 1994). However, the lethality of the GGTase I null mutation presumably results from the inability of $S$. cerevisiae FTase to sufficiently prenylate wild-type levels of Cdc42p (CTIL) and Rho1p (CVLL) in the mutant yeast cells. The C. albicans GGTase I exhibits the same preference for the geranylgeranylation of Ras-CaaL substrates as observed with both $S$. cerevisiae and mammalian GGTase I enzymes. However, the $K_{\mathrm{m}}$ values determined for Ras-CaaL substrates, particularly CTIL and CAIL, were unusually high compared to values observed for $S$. cerevisiae and mammalian GGTase I, which are typically $5 \mu \mathrm{M}$ or less. The reduced GGTase I activity with RasCTIL and RasCAIL probably reflects the higher $K_{\mathrm{m}}$ values observed with these substrates. The C. albicans FTase has a strong preference for farnesylation of Ras-CVLM as does $S$. cerevisiae FTase, but in contrast, has quite modest activity with RasCVLS or Ras-CVIA (yeast a-factor mating pheromone). Interestingly, the C. albicans FTase also possesses the ability to farnesylate all Ras-CaaL substrates examined at levels ranging from $2 \%$ (CAIL) to $20 \%$ (CVIL) relative to that observed with CVLM. Moreover, the specific activities determined for CaaL farnesylation are comparable to those observed for GGTase I catalysed geranylgeranylation. It is unclear whether the crossspecificity of C. albicans FTase for CaaL substrates observed in vitro will affect the functional requirements for GGTase I in C. albicans cells.

The cloning of the C. albicans GGTase I subunit genes is an important step towards understanding the role of protein geranylgeranylation in C. albicans morphogenesis. The sequence data presented suggest that it may be possible to identify inhibitors with selectivity for the C. albicans versus the human enzyme. Further experiments to validate GGTase I as a broad-spectrum fungicidal target for antimycotic therapy are under way.

\section{NOTE ADDED IN PROOF}

A report on the complete cloning and characterization of GGTase I from the fission yeast Schizosaccharomyces pombe was published recently (Arellano et al., 1998).

\section{ACKNOWLEDGEMENTS}

We are grateful to John Rosamond for providing the CA124 C. albicans genomic DNA library, Cam Douglas for providing genomic DNA, Charles Omer for providing Ras-CaaX plasmids, and Terri Kelly and Wanda Seyton for providing Ras-CVVL and Ras-CVIA. We thank Peggy Carver for construction of plasmids pCaRAM2T and p40CDCU. We thank Charles Omer and Toshihiko Satoh for helpful discussions. We appreciate the critical reading of the manuscript by Cam Douglas, Terri Kelly, Suzanne Mandala and Kenny Wong.

\section{REFERENCES}

Abruzzo, G. K., Flattery, A. M. , Gill, C. J. , Kong, L., Smith, J. G., Krupa, D., Pikounis, V. B., Kropp, H. \& Bartizal, K. (1995). Evaluation of water-soluble pneumocandins L-733,560, L705,589, and L-731,373 in mouse models of disseminated aspergillosis, candidiasis, and cryptococcosis. Antimicrob Agents Chemother 39, 1077-1081.

Adams, E. M., Johnson, D. l., Longnecker, R. M., Sloat, B. F. \& Pringle, J. R. (1990). CDC42 and CDC43, two additional genes involved in budding and the establishment of cell polarity in the yeast Saccharomyces cerevisiae. J Cell Biol 111, 131-142.

Arellano, M., Coll, P. M., Yang, W., Duran, A., Tamanoi, F. \& Perez, P. (1998). Characterization of the geranylgeranyl trans- 
ferase type I from Schizosaccharomyces pombe. Mol Microbiol 29, 1357-1367.

Boeke, J. D., LaCroute, F. \& Fink, G. R. (1984). A positive selection for mutants lacking orotidine-5'-phosphate decarboxylase activity in yeast: 5-fluoro-orotic acid resistance. Mol Gen Genet $197,345-346$.

Boguski, M. S., Murray, A. W. \& Powers, S. (1992). Novel repetitive sequence motifs in the $\alpha$ and $\beta$ subunits of prenylprotein transferases and homology of the $\alpha$ subunit to the MAD2 gene product of yeast. New Biol 4, 408-411.

Caplin, B. E., Hettich, L. A. \& Marshall, M. S. (1994). Substrate characterization of the Saccharomyces cerevisiae protein farnesyltransferase and type-I protein geranylgeranyltransferase. Biochim Biophys Acta 1205, 39-48.

Christianson, T. W., Sikorski, R. S., Dante, M., Shero, J. H. \& Hieter, P. (1992). Multifunctional yeast high-copy-number shuttle vectors. Gene 110, 119-122.

Clarke, S. (1992). Protein isoprenylation and methylation at carboxyl-terminal cysteine residues. Annu Rev Biochem 61, 355-386.

Compton, T. (1990). Degenerate primers for DNA amplification. In PCR Protocols: a Guide to Methods and Applications, pp. 39-45. Edited by M. A. Innis, D. H. Gelfand, J. J. Sninsky \& T. J. White. New York: Academic Press.

Cox, G. M. \& Perfect, J. R. (1993). Fungal infections. Curr Opin Infect Dis 6, 422-426.

Diffley, J. F. X. \& Stillman, B. (1989). Similarity between the transcriptional silencer binding proteins ABF1 and RAP1. Science 246, 1034-1038.

Douglas, C. M., Foor, F., Marrinan, J. A. \& 11 other authors (1994). The Saccharomyces cerevisiae FKS1 (ETG1) gene encodes an integral membrane protein which is a subunit of $1,3-\beta$-D-glucan synthase. Proc Natl Acad Sci USA 91, 12907-12911.

Drgonová, J., Drgon, T., Tanaka, K., Kollár, R., Chen, G.-C., Ford, R. A., Chan, C. S. M., Takai, Y. \& Cabib, E. (1996). Rho1p, a yeast protein at the interface between cell polarization and morphogenesis. Science 272, 277-279.

Elble, R. (1992). A simple and efficient procedure for transformation of yeasts. Biotechniques 13, 18-20.

Farnsworth, C. C., Seabra, M. C., Ericsson, L. H., Gelb, M. H. \& Glomset, J. A. (1994). Rab geranylgeranyl transferase catalyzes the geranylgeranylation of adjacent cysteines in the small GTPases Rab1A, Rab3A, and Rab5A. Proc Natl Acad Sci USA 91, 11963-11967.

Finegold, A. A., Johnson, D. I., Farnsworth, C. C., Gelb, M. H., Judd, S.R., Glomset, J.A. \& Tamanoi, F. (1991). Geranylgeranylprotein transferase of Saccharomyces cerevisiae is specific for Cys-Xaa-Xaa-Leu motif proteins and requires the CDC43 gene product, but not the DPR1 gene product. Proc Natl Acad Sci USA 88, 4448-4452.

Fonzi, W. A. \& Irwin, M. Y (1993). Isogenic strain construction and gene mapping in Candida albicans. Gene 134, 717-728.

Gietz, R. D. \& Sugino, A. (1988). New yeast-Escherichia coli shuttle vectors constructed with in vitro mutagenized yeast genes lacking six-base pair restriction sites. Gene 74, 527-534.

Goodman, L. E., Judd, S. R., Farnsworth, C. C., Powers, S., Gelb, M. H., Glomset, J. A. \& Tamanoi, F. (1990). Mutants of Saccharomyces cerevisiae defective in the farnesylation of Ras proteins. Proc Natl Acad Sci USA 87, 9665-9669.

He, B., Chen, P., Chen, S., Vancura, K. L., Michaelis, S. \& Powers, S. (1991). RAM2, an essential gene of yeast, and RAM1 encode the two polypeptide components of the farnesyltransferase that prenylates a-factor and Ras proteins. Proc Natl Acad Sci 88, 11373-11377.

Hoffman, C. S. \& Winston, F. (1987). A ten-minute DNA preparation from yeast efficiently releases autonomous plasmid for transformation of Escherichia coli. Gene 57, 267-272.

Imamura, H., Tanaka, K., Hihara, T., Umikawa, M., Kamei, T., Takahashi, K. \& Sasaki, T. (1997). Bnilp and Bnrlp: downstream targets of the Rho family small G-proteins which interact with profilin and regulate actin cytoskeleton in Saccharomyces cerevisiae. EMBO J 16, 2745-2755.

Jones, J. S. \& Prakash, L. (1990). Yeast Saccharomyces cerevisiae selectable markers in pUC18 polylinkers. Yeast 6, 363-366.

Kamada, Y., Qadota, H., Python, C. P., Anraku, Y., Ohya, Y. \& Levin, D. E. (1996). Activation of yeast protein kinase C by Rho1 GTPase. J Biol Chem 271, 9193-9196.

Kelly, R., Miller, S. M., Kurtz, M. B. \& Kirsch, D. R. (1987). Directed mutagenesis in Candida albicans: one-step gene disruption to isolate ura3 mutants. Mol Cell Biol 7, 199-208.

Kohl, N. E., Diehl, R. E., Schaber \& 9 other authors (1991). Structural homology among mammalian and Saccharomyces cerevisiae isoprenyl-protein transferases. J Biol Chem 266, 18884-18888.

Kohno, H., Tanaka, K., Mino, A., Umikawa, M., Imamura, H., Fujiwara, T., Fujita, Y., Hotta, K. \& Qadota, H. (1996). Bni1p implicated in cytoskeletal control is a putative target of Rholp small GTP binding protein. EMBO J 15, 6060-6068.

Kondoh, O., Tachibana, Y., Ohya, Y., Arisawa, M. \& Watanabe, T. (1997). Cloning of the RHO1 gene from Candida albicans and its regulation of $\beta-1,3$-glucan synthesis. J Bacteriol 179, 7734-7741.

Kral, A. M., Diehl, R. E., deSolms, S. J., Williams, T. M., Kohl, N. E. \& Omer, C. A. (1997). Mutational analysis of conserved residues of the $\beta$-subunit of human farnesyl:protein transferase. $J$ Biol Chem 272, 27319-27323.

Mayer, M. L., Caplin, B. E. \& Marshall, M. S. (1992). CDC43 and RAM2 encode the polypeptide subunits of a yeast type I protein geranylgeranyltransferase. J Biol Chem 267, 20589-20593.

Mazur, P. \& Baginsky, W. (1996). In vitro activity of $1,3-\beta$-Dglucan synthase requires the GTP-binding protein Rho1. J Biol Chem 271, 14604-14609.

Mirbod, F., Nakashima, S., Kitajima, Y., Cannon, R. D. \& Nozawa, Y. (1997). Molecular cloning of a Rho family, $C D C 42 \mathrm{Ca}$ gene from Candida albicans and its mRNA expression changes during morphogenesis. J Med Vet Mycol 35, 173-179.

Moores, S. L., Schaber, M. D., Mosser, S. D., Rands, E., O'Hara, M. B., Garsky, V. M., Marshall, M. S., Pompliano, D. L. \& Gibbs, J. B. (1991). Sequence dependence of protein isoprenylation. J Biol Chem 22, 14603-14610.

Nonaka, H., Tanaka, K., Hirano, H., Fujiwara, T., Kohno, H., Umikawa, M., Mino, A. \& Takai, Y. (1995). A downstream target of $R H O 1$ small GTP-binding protein is PKC1, a homolog of protein kinase $\mathrm{C}$, which leads to activation of the MAP kinase cascade in Saccharomyces cerevisiae. EMBO J 14, 5931-5938.

Ohya, Y., Goebl, M., Goodman, L. E., Peterson-Bjorn, S., Friesen, J. D., Tamanoi, F. \& Anraku, Y. (1991). Yeast CAL1 is a structural and functional homologue to the DPR1 (RAM) gene involved in ras processing. J Biol Chem 266, 12356-12360.

Ohya, Y., Qadota, H., Anraku, Y., Pringle, J. R. \& Botstein, D. (1993). Suppression of yeast geranylgeranyl transferase I defect by alternative prenylation of two target GTPases, Rho1p and Cdc42p. Mol Biol Cell 4, 1017-1025.

Ohya, Y., Caplin, B. E., Qadota, H., Tibbetts, M. F., Anraku, Y., Pringle, J. R. \& Marshall, M. S. (1996). Mutational analysis of the 
$\beta$-subunit of yeast geranylgeranyl transferase I. Mol Gen Genet $252,1-10$.

Omer, C. \& Gibbs, J. (1994). Protein prenylation in eukaryotic microorganisms : genetics, biology and biochemistry. Mol Microbiol 11, 219-225.

Park, H.-W. \& Beese, L. S. (1997). Protein farnesyltransferase. Curr Opin Struct Biol 7, 873-880.

Park, H.-W., Boduluri, S. R., Moomaw, J. F., Casey, P. J. \& Beese, L. S. (1997). Crystal structure of protein farnesyltransferase at $2 \cdot 5$ angstrom resolution. Science 21, 1800-1804.

Qadota, H., Python, C. P., Inoue, S. B., Arisawa, M., Anraku, Y., Zheng, Y., Watanabe, T., Levin, D. E. \& Ohya, Y. (1996). Identification of yeast Rho1p GTPase as a regulatory subunit of 1,3- $\beta$-glucan synthase. Science 272, 279-281.

Schafer, W. R. \& Rine, J. (1992). Protein prenylation: genes, enzymes, targets, and functions. Annu Rev Genet 30, 209-237.

Schmalix, W. A. \& Bandlow, W. (1994). $S W H 1$ from yeast encodes a candidate nuclear factor containing ankyrin repeats and showing homology to mammalin oxysterol-binding protein. Biochim Biophys Acta 1219, 205-210.

Sherlock, G., Gahman, A. M., Mahal, A., Shieh, J., Ferreira, M. \& Rosamond, J. (1994). Molecular cloning and analysis of CDC28 and cyclin homologues from the human fungal pathogen Candida albicans. Mol Gen Genet 245, 716-723.

Sherman, F., Fink, G. R. \& Hicks, J. B. (1986). Methods in Yeast Genetics: a Laboratory Course Manual. Cold Spring Harbor, NY : Cold Spring Harbor Laboratory.

Thomas, B. \& Rothstein, R. (1989). Elevated recombination rates in transcriptionally active DNA. Cell 56, 619-630.
Thompson, J. D., Higgins, D. G. \& Gibson, T. J. (1994). CLUSTAL w : improving the sensitivity of progressive multiple sequence alignment through sequence weighting, position-specific gap penalties and weight matrix choice. Nucleic Acids Res 22, 4673-4680.

Trueblood, C. E., Ohya, Y. \& Rine, J. (1993). Genetic evidence for in vivo cross-specificity of the CaaX-box protein prenyltransferases farnesyltransferase and geranylgeranyltransferase-I in Saccharomyces cerevisiae. Mol Cell Biol 13, 4260-4275.

Tuite, M. F. \& Santos, M. A. (1996). Codon reassignment in Candida species: an evolutionary conundrum. Biochimie 78 , 993-999.

Yalovsky, S., Trueblood, C. E., Callan, K. L., Narita, J. O., Jenkins, S. M., Rine, J. \& Gruissem, W. (1997). Plant farnesyltransferase can restore yeast Ras signaling and mating. Mol Cell Biol 17, 1986-1994.

Yanisch-Perron, C., Vieira, J. \& Messing, J. (1985). Improved M13 phage cloning vectors and host strains: nucleotide sequences of the M13mp18 and pUC19 vectors. Gene 33, 103-119.

Zaret, K. S. \& Sherman, F. (1982). DNA sequence required for efficient transcription termination in yeast. Cell 28, 563-573.

Zhang, F. L. \& Casey, P. J. (1996a). Protein prenylation: molecular mechanisms and functional consequences. Annu Rev Biochem 65, 241-269.

Zhang, F. L. \& Casey, P. J. (1996b). Influence of metal ions on substrate binding and catalytic activity of mammalian protein geranylgeranyltransferase type-I. Biochem J 320, 925-932.

Received 3 November 1998; revised 8 January 1999; accepted 13 January 1999. 